\title{
Desulfurisasi Katalitik Tiofen Menggunakan Katalis CoMo/USY dalam Reaktor Batch
}

\author{
Khoirina Dwi Nugrahaningtyas $^{\left.\mathrm{a}^{*}\right)}$, Nanda Pratiwi ${ }^{\text {a }}$, Eddy Heraldy ${ }^{\mathrm{a}}$ \\ ${ }^{a}$ Program Studi Kimia, Fakultas Matematika dan Ilmu Pengetahuan Alam, Universitas Sebelas Maret, Jl. Ir \\ Sutami No.36A, Kentingan-Jebres Surakarta, Jawa Tengah, Indonesia, 57126. \\ * Corresponding author \\ E-mail: khoirina@mipa.uns.ac.id \\ DOI: 10.20961/alchemy.14.1.2368.119-130
}

Received 12 February 2016, Accepted 29 November 2017, Published 1 March 2018

\begin{abstract}
ABSTRAK
Telah dilakukan uji aktivitas katalis CoMo/USY pada reaksi desulfurisasi tiofen. Reaksi dilakukan pada reaktor sistem batch dengan tekanan gas $\mathrm{N}_{2}$ sebesar 1 bar gas $\mathrm{N}_{2}$ dan waktu reaksi selama 1 jam. Penelitian ini bertujuan untuk mengetahui pengaruh variasi temperatur dan variasi karakter katalis pada reaksi desulfurisasi tiofen. Product desulfurisasi dianalisis dengan Gas Chromatography - Mass Spectra (GCMS). Karakter kestabilan struktur katalis dilihat dengan analisis menggunakan instrumen Fourier Transform Infrared Spectroscopy (FT-IR). Hasil analisis terhadap uji aktivitas desulfurisasi menunjukkan bahwa pada rentang temperatur $200-300^{\circ} \mathrm{C}$, rendemen bertambah dengan meningkatnya temperatur. Pada penelitian telah berhasil menghidrogenasi tiofen, tetapi belum bisa menghilangkan kandungan sulfurnya. Adapun efek karakter katalis terhadap aktivitas katalitiknya menunjukkan bahwa karakter katalis yang paling dominan adalah sifat keasaman. Katalis dengan keasaman tertinggi, yaitu katalis CoMo/USY, memiliki aktivitas tertinggi dengan rendemen produk sebesar 2,88\%. Hasil analisis FT-IR terhadap katalis bekas menunjukkan bahwa struktur cukup stabil dan tidak ada pengotor yang terikat pada katalis.
\end{abstract}

Kata Kunci: desulfurisasi, katalis CoMo/USY, tiofen

\section{ABSTRACT}

Catalytic Desulfurization of Thiophene using CoMo/USY Catalyst in Batch Reactor. $\mathrm{CoMo} / \mathrm{USY}$ catalyst activity has been tested for thiophene desulfurization reaction. The reaction was carried out in batch system reactor with $\mathrm{N}_{2}$ gas pressure of 1 bar and reaction time for 1 hour. This study aims to determine the effect of temperature variation and catalyst character variation in thiophene desulfurization reaction. The desulfurization products were analyzed by Gas Chromatography - Mass Spectra (GC-MS). The characters of structure catalyst were analyzed by Fourier Transform Infrared Spectroscopy (FT-IR). The results of the analysis of the desulfurization activity test showed that in the temperature range $200-300{ }^{\circ} \mathrm{C}$, the yield raised with increasing temperature. The analysis results of the desulfurization activity test showed that in the temperature range of $200-300^{\circ} \mathrm{C}$, the yield raised with increasing temperature. The study has successfully hydrogenated thiophene, but has not been able to eliminate the sulfur content. The effect of the catalysts character on its catalytic activity shows that the most dominant character of the catalysts was its acidity. The highest acidity catalyst, CoMo/USY catalyst, has highest activity with the product yield of 
2,88\%. The result of the FTIR analysis on the used catalyst show that the structure was stable and no impurities were attached the catalyst.

Keyword: catalyst CoMo/USY, desulfurization, thiophene.

\section{PENDAHULUAN}

Bahan bakar fosil merupakan sumber energi utama yang digunakan diseluruh dunia saat ini. Konsumsi bahan bakar yang berlebihan ini menyebabkan masalah pada lingkungan seperti polusi udara. Ketika dalam proses pembakaran, bahan bakar fosil melepaskan gas karbon dioksida, nitrogen dioksida, sulfur dioksida, karbon monoksida, dan gas lainnya yang dapat merugikan lingkungan. Salah satu masalah yang cukup serius bagi lingkungan adalah keberadaan komponen sulfur dalam bahan bakar minyak bumi ini yang menimbulkan polutan gas $\mathrm{SO}_{2}$ (Jeevanandam et al., 2005). Selain itu, kehadiran kontaminan berupa sulfur ini akan berakibat pada kerusakan mesin kendaraan (Topsøe et $a l .$, 1996). Oleh karena itu pengotor-pengotor tersebut harus dihilangkan melalui proses hydrotreating yang salah satu yang paling penting yaitu meliputi proses penghilangan sulfur sebelum minyak bumi diolah lebih lanjut. Proses penghilangan sulfur dapat dilakukan dengan desulfurisasi (Nava et al., 2007).

Salah satu parameter penting dalam proses desulfurisasi katalitik adalah penggunaan katalis yang memiliki aktivitas yang baik dan stabil. Salah satu katalis yang berpotensi sebagai katalis desulfurisasi adalah katalis CoMo/USY. Menurut TorresMancera et al. (2005) katalis bimetal CoMo baik untuk desulfurisasi. Pengemban USY memiliki aktivitas katalitik lebih baik dibandingkan dengan $\mathrm{Al}_{2} \mathrm{O}_{3}$ dalam desulfurisasi tiofen (Rawat et al., 2010). Logam Co dan USY berperan dalam hidrogenasi dan dehidrogenasi (Nugrahaningtyas et al., 2009; Wang and Iglesia, 2010), sedangkan logam Mo yang berperan dalam proses penghilangan sulfur (Liu et al., 2015). Oleh karena itu, paduan logam CoMo/USY mampu memiliki aktivitas katalitik yang tinggi. Sebelum dilakukannya uji katalitik, katalis harus diaktivasi dahulu untuk meningkatkan aktivitas katalitiknya. Proses aktivsasi katalis dapat dilakukan secara fisika maupun kimia. Deng et al. (2014) melaporkan bahwa aktivasi katalis $\mathrm{Pt}-\mathrm{Sn} / \mathrm{SiO}_{2}$ mempengaruhi karakter katalis tersebut. Hasil penelitian Pawelec et al. (2008) menunjukkan bahwa karakter katalis mempengaruhi aktivitas katalitiknya. Hal tersebut sesuai dengan hasil penelitian Deng et al. (2014) yang menunjukkan bahwa aktivitas katalis $\mathrm{Pt}-\mathrm{Sn} / \mathrm{SiO}_{2}$ yang diaktivasi dengan 
cara perpaduan kalsinasi-reduksi lebih baik dibandingkan aktivasi dengan kalsinasi atau perpaduan kalsinasi-oksidasi-reduksi.

Uji aktivitas katalitik desulfurisasi biasanya menggunakan senyawa model yang mampu mewakili senyawa sulfur yang terkandung didalam minyak bumi. Salah satu senyawa model yang sering digunakan adalah tiofen (Xu et al., 2011). Uji ativitas katalitik dipengaruhi antara lain oleh temperatur reaksi. Secara kinetik, semakin tinggi temperatur pada proses reaksi kimia, maka laju reaksi akan berlangsung semakin cepat. Namun temperatur yang terlalu tinggi dapat juga menyebabkan kerusakan pada struktur katalis. Oleh sebab itu, temperatur dalam proses desulfurisasi harus dioptimalkan untuk mendapatkan hasil yang maksimal (Boukoberine and Hamada, 2016). Selain temperatur, aktivitas katalitik juga dipengaruhi oleh karakter katalis.

Deaktivasi katalis dapat terjadi karena adanya kerusakan struktur katalis maupun karena adanya kokas sebagai produk samping dari reaksi katalitik (Ravanchi and Sahebdelfar, 2016). Oleh karena itu perlu dilakukan karakterisasi katalis bekas untuk mengetahui karakter kestabilan struktur katalis.

Berdasarkan latar belakang tersebut, maka penelitian ini bertujuan untuk mengetahui pengaruh temperatur dan karakter katalis pada reaksi desulfurisasi tiofen. Selain itu, dalam penelitian ini ditinjau pula adanya deaktivasi katalis karena terikatnya kokas dipermukaan katalis setelah uji aktivitas katalitik.

\section{METODE PENELITIAN}

Bahan yang digunakan dalam penelitian ini adalah $\mathrm{NH}_{4}-\mathrm{Y}$ zeolit yang diperoleh dari Tosoh Inc. (Japan), garam logam prekursor $\left.\left(\mathrm{NH}_{4}\right)_{6} \mathrm{Mo}_{7} \mathrm{O}_{24} \cdot 4 \mathrm{H}_{2} \mathrm{O}\right]$ (pa E Merck, garam logam prekursor $\left[\mathrm{Co}\left(\mathrm{NO}_{3}\right)_{2} \cdot 6 \mathrm{H}_{2} \mathrm{O}\right]$ pa E Merck, , Gas $\mathrm{N}_{2}$ kemurnian 99,99\% (Samator), dan Tiofen (p.a E Merck). Adapun peralatan utama dalam penelitian ini, adalah satu set alat refluks, satu set evaporator Buchii, satu set reaktor batch, GC-MS type Shimadzu tipe QP 2010 SE, dan FT-IR type Shimadzu 8201 PC.

\section{Prosedur Penelitian}

Tahap pertama penelitian adalah preparasi H USY dengan metode kalsinasi NH4 Y Zeolit pada temperatur $550{ }^{\circ} \mathrm{C}$ selama 3 jam. Tahap berikutnya adalah pembuatan katalis logam bimetal Co dan Mo dengan pengemban H-USY dilakukan dengan metode koimpregnasi dan impregnasi berurutan mengacu pada prosedur yang dilakukan oleh 
(Nugrahaningtyas et al., 2014). Katalis yang diperoleh kemudian diaktivasi dengan cara kalsinasi dan reduksi. Sampai tahap ini diperoleh katalis yang dibuat dengan metode koimpregnasi disebut CoMo/USY, katalis yang dibuat dengan metode impregnasi Co dilanjutkan Mo disebut katalis Co-Mo/USY dan katalis yang dibuat dengan etode imregnasi Mo dilanjutkkan Co disebut katalis MoCo/USY.

Uji aktivitas katalis dilakukan dengan sistem reaktor batch (Gambar 1). Sebanyak 0,5 g katalis pelet dan $5 \mathrm{~mL}$ senyawa model tiofen dimasukkan kedalam reaktor. Setelah instalasi rangkaian reaktor selesai dilakukan purging selama 5 menit dan mengatur tekanan 1 bar gas $\mathrm{N}_{2}$. Temperatur diatur hingga mencapai reaksi yang diinginkan, dengan variasi 200, 250 dan $300{ }^{\circ} \mathrm{C}$. Setelah diperoleh temperatur terbaik maka dilanjutkan variasi katalis CoMo/USY, Co-Mo/USY, dan Mo-Co/USY.

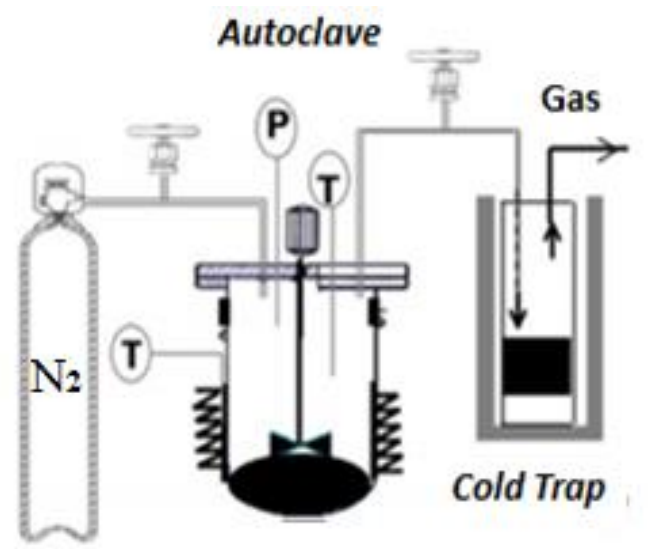

Keterangan Gambar:

P: Pengatur tekanan

T: Pengatur temperatur

Gambar 1. Rangkaian Alat Uji Aktivitas Katalis (Larabi et al., 2016)

Produk cair yang diperoleh dianalisis dengan alat GC-MS. Berdasarkan data kromatogram yang diperoleh, maka dihitung rendemen produk total dengan rumus (1) sebagai berikut:

$$
\text { Rendemen produk total }=\% \text { area produk cair } \times \frac{\text { Volume produk }}{\text { Volume Awal }}
$$

Selanjutnya katalis fresh dan katalis yang telah digunakan untuk uji katalitik (sebagai katalis bekas) dianalisis menggunakan FT-IR untuk melihat kestabilan katalis berdasarkan perubahan pita serapan gugus fungsinya

\section{PEMBAHASAN}

\section{Karakter Katalis}


Karakter katalis CoMo/USY dipengaruhi oleh metode preparasinya, seperti hasil penelitian Pawelec et al., (2008). Hasil penelitian Pawelec et al., (2008) menunjukkan bahwa karakter katalis $\mathrm{Co} / \mathrm{Mo} / \mathrm{P} / \mathrm{Ti}-\mathrm{HMS}$ dan $\mathrm{CoMo} / \mathrm{P} / \mathrm{Ti}-\mathrm{HMS}$ dengan metode preparasi berbeda mempunyai sifat keasaman dan aktivitas yang berbeda pula. Hal tersebut juga terjadi pada hasil penelitian ini, pada ketiga jenis katalis CoMo/USY tersebut, keasaman, luas permukaan spesifik dan partikel terkandung yang berbeda-beda pula. Data karakter tersebut disajikan pada penelitian sebelumnya oleh Rachmadhani (2016).

Berdasarkan data Rachmadhani (2016), terlihat bahwa keasaman terbaik dimiliki oleh katalis CoMo/USY, adapun luas permukaan spesifik dan partikel terkandung tertinggi dimiliki oleh katalis Co-Mo/USY. Oleh karena itu, dilakukan uji aktivitas katalis untuk menentukan pengaruh karakter yang dominan pada reaksi desulfurisasi tiofen.

\section{Uji Aktivitas Katalis}

Hasil uji aktivitas katalis pada reaksi desulfurisasi tiofen yang disajikan pada Gambar 2. Aktivitas katalis dapat ditentukan berdasarkan nilai rendemen total yang diperoleh.

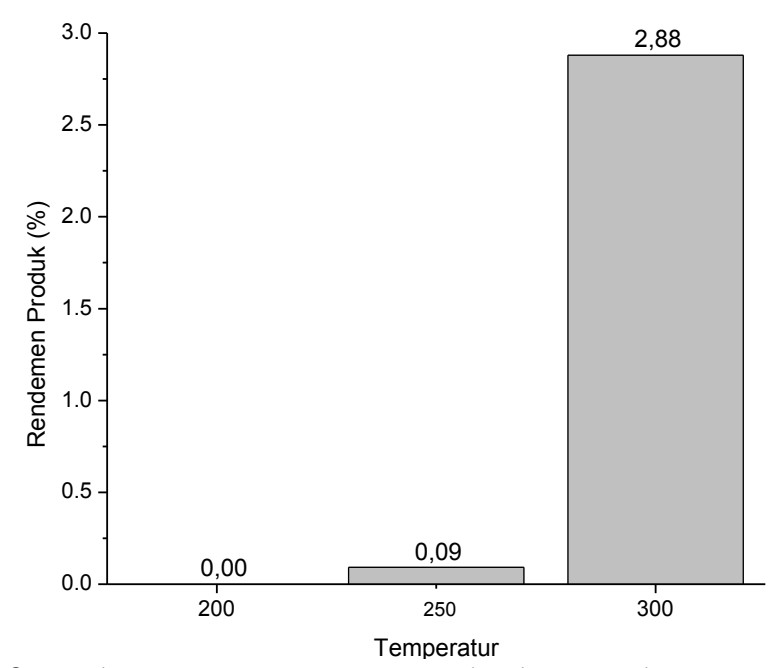

Gambar 2. Hubungan temperatur terhadap rendemen produk total

Nilai rendemen total yang diperoleh dalam penelitian ini menunjukkan bahwa katalis yang dibuat bisa disetarakan dengan katalis yang dibuat oleh (Souza et al., 2015) maupun (Yu et al., 1999). Nilai rendemen total yang diperoleh pada penelitian ini hanya berbeda tipis dengan nilai rendemen total dari kedua peneliti sebelumnya. Padahal, uji aktivitas katalitik yang dilakukan pada penelitian ini tidak melibatkan kehadiran gas hidrogen sebagai sumber hidrogen, sedangkan kedua peneliti sebekumnya menambahkan gas hidrogen untuk suplay $\mathrm{H}$. Hal ini menjadi bukti bahwa aktivitas katalitik CoMo/USY 
mirip bahkan mungkin lebih baik jika dibandingkan dengan katalis yang dibuat oleh kedua peneliti sebelumnya.

Berdasarkan data pada Gambar 2 terlihat bahwa rendemen produk senyawa tiofen terus meningkat seiring dengan naiknya temperatur dalam rentang 200-300 ${ }^{\circ} \mathrm{C}$. Hasil penelitian tersebut sesuai dengan hasil penelitian (Yaseen et al., 2012) yang memperoleh kesimpulan bahwa reaksi desulfurisasi menyukai reaksi endotermis dimana untuk memutus ikatan diperlukan energi panas.

Berdasarkan kesimpulan Yaseen et al. (2012), dapat diartikan bahwa dengan semakin meningkatnya temperatur, laju reaksi akan semakin naik. Fenomena tersebut terjadi karena dengan semakin meningkatnya temperatur reaksi maka semakin besar energi yang tersedia untuk terjadinya vibrasi, rotasi, dan translasi pada molekul-molekul reaktan. Disamping itu juga akan semakin besar pula kemungkinan terjadinya tumbukan antar katalis dengan reaktan serta reaktan dengan reaktan. Adanya tumbukan tumbukan tersebut akan menyebabkan reaksi berupa pemutusan ikatan yang terjadi menjadi semakin cepat. Selain itu, temperatur yang semakin tinggi juga akan meningkatkan laju osmosis komponen senyawa sulfur menuju pori sisi aktif katalis (Jarullah et al., 2011). Senyawa aromatik sulfur serta turunannya yang tidak aktif menjadi teraktifkan dan bereaksi dengan hidrogen dengan mendekomposisi senyawa aromatik menjadi molekul yang lebih kecil kemudian berdifusi ke pori katalis (Mohammed et al., 2008).

Titik optimum belum diperoleh pada rentang temperatur $200-300{ }^{\circ} \mathrm{C}$, hal ini dikarenakan secara teori semakin tinggi temperatur suatu reaksi maka laju reaksi akan semakin cepat (Jarullah et al., 2011). Fenomena tersebut terjadi sampai pada suatu titik optimum, dimana pada temperatur yang terlalu tinggi akan mengakibatkan reaktan terdesorpsi kembali sebelum terjadi reaksi sehingga laju reaksi akan turun. Adapun artinya adalah bahwa dalam rentang temperatur penelitian ini katalis yang digunakan bersifat stabil dan tidak mengalami penurunan aktivitas. Hal ini serupa dengan penelitian Souza et al. (2015) pada katalis PtMo/MCM-48 dalam rentang 250-375 ${ }^{\circ} \mathrm{C}$ memiliki tren semakin tinggi katalis, semakin baik aktivitas desulfurisasi yang dimilikinya.

Rendemen mengalami peningkatan $100 \%$ pada saat temperatur reaksi dinaikkan $100{ }^{\circ} \mathrm{C}$ terhadap temperatur awal $200{ }^{\circ} \mathrm{C}$. Adapun pada kenaikan temperatur $50{ }^{\circ} \mathrm{C}$ terhadap temperatur awal $200{ }^{\circ} \mathrm{C}$ mengalami kenaikan hanya sebesar 3,13\%. Berdasarkan data seperti yang tersaji pada Gambar 2, kenaikan $50{ }^{\circ} \mathrm{C}$ terhadap temperatur $250{ }^{\circ} \mathrm{C}$ 
mengalami peningkatan yang sangat signifikan. Oleh karena itu, dalam penelitian ini temperatur efektif katalis berada pada rentang 250-300 ${ }^{\circ} \mathrm{C}$. Hasil tersebut sesuai dengan penelitian Wang et al. (2015) yang melaporkan bahwa dalam reaksi desulfurisasi tiofen, katalis $\mathrm{Mo} / \mathrm{AC}$ presulfidasi teraktifkan pada temperatur $250-300{ }^{\circ} \mathrm{C}$. Oleh karena itu, dalam reaksi desulfurisasi katalitik pada variasi karakter katalis maupun jenis umpan dilakukan pada temperatur $300{ }^{\circ} \mathrm{C}$.

Berdasarkan Gambar 3 terlihat bahwa dalam reaksi desulfurisasi tiofen, katalis CoMo/USY memiliki rendemen produk cair tertinggi. Hal ini dapat dijelaskan karena berdasarkan sifat keasamannya,katalis CoMo/USY memiliki keasaman yang tinggi dibandingkan katalis lainnya dengan urutan nilai keasaman katalis CoMo/USY 11,206 $\mathrm{mmol} / \mathrm{g}>>$ Co-Mo/USY 10,849 mmol/g >> Mo-Co/USY 8,304 mmol/g. Trend ini serupa juga dengan aktivitas katalitiknya. Hal ini sesuai dengan penelitian Pawelec et al.(2008), bahwa semakin tinggi sifat keasaman suatu katalis mampu meningkatkan aktivitas suatu katalis.

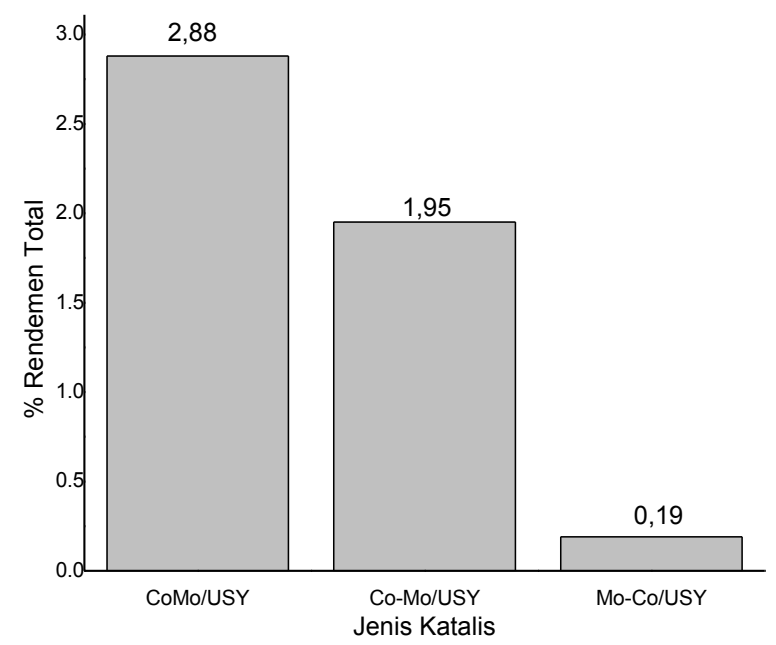

Gambar 3. Pengaruh karakter katalis terhadap rendemen produk total

Hasil analisis GC-MS terhadap produk cair desulfurisasi tiofen menunjukkan rendemen produk yang berhasil terdeteksi hanya sebagai produk hasil hidrogenasi yaitu tetrahidrotiofen. Besarnya rendemen produk desulfurisasi tiofen menjadi produk antara tetrahidrotiofen ditunjukkan melalui Gambar 4.

Berdasarkan Gambar 4 terlihat bahwa rendemen produk tertinggi dimiliki oleh katalis Co-Mo/USY. Hal ini dapat dijelaskan bahwa reaksi yang terjadi pada desulfurisasi tiofen menjadi tetrahidrotiofen adalah reaksi hidrogenasi. Oleh karena itu, yang lebih berperan dominan terhadap jalannya reaksi ini adalah kehadiran logam Co dan USY. Hal 
ini diduga karena terdapatnya logam Co sebagai logam murni yang memiliki keasaman yang lebih tinggi dibandingkan dengan logam oksidanya. Sementara itu, USY berperan menyediakan situs situs asam Brønsted pada reaksi hidrogenasi tersebut.. Hasil penelitian tersebut sesuai dengan hasil penelitian sebelumnya Sullivan and Ekerdt (1998) dan (Moses et al., 2007). Berdasarkan penelitian Sullivan and Ekerdt (1998) dan (Moses et al., 2007) diperoleh bahwa dalam reaksi hidrodesulfurisasi atau desulfurisasi terdapat dua jalur mekanisme reaksi, yaitu: (1) jalur reaksi hidrogenasi (HYD); cincin aromatik dihidrogenasi terlebih dahulu, kemudian dilanjutkan dengan pemutusan ikatan C-S dan (2) jalur direct desulfurization (DDS); pemutusan langsung ikatan C-S. Adapun mekanisme reaksi jalur 1 seperti yang ditunjukkan melalui Gambar 5.

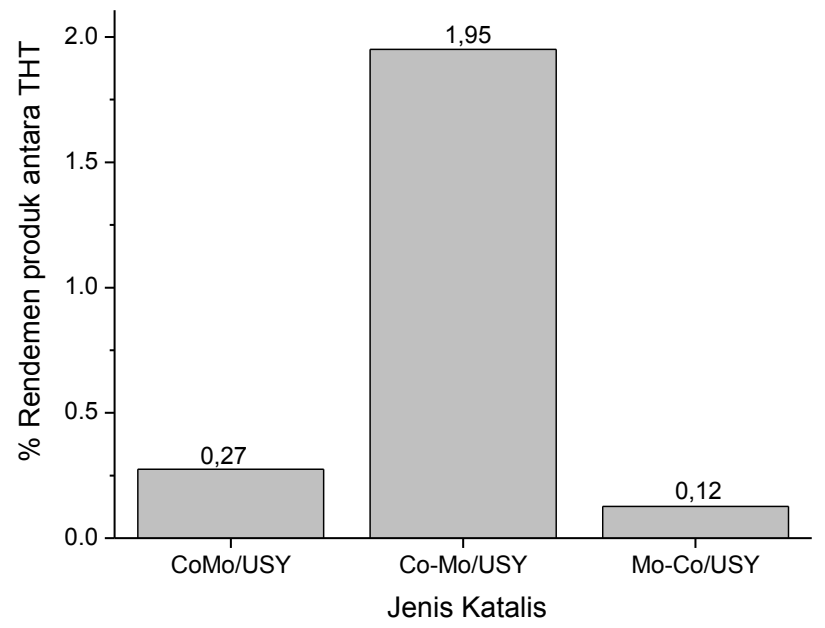

Gambar 4. Hubungan jenis katalis terhadap rendemen produk antara THT dalam reaksi desulfurisasi tiofen
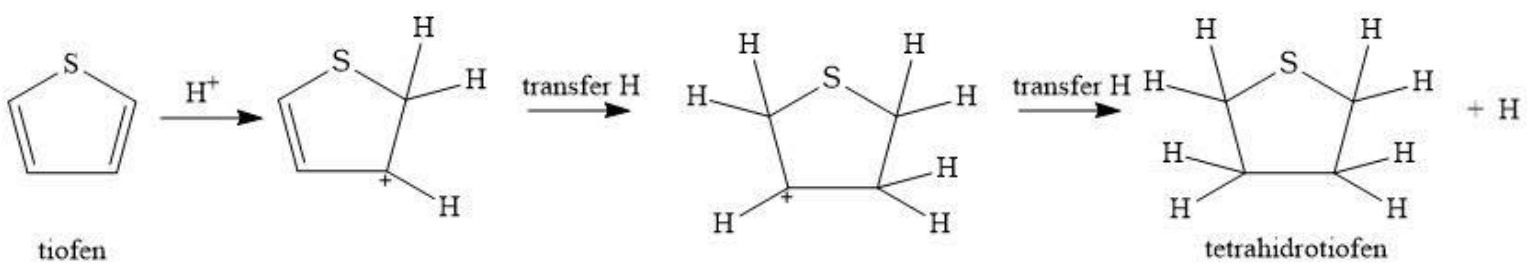

Gambar 5. Reaksi desulfurisasi tiofen menjadi produk antaratetrahidrotiofen (Sullivan and Ekerdt, 1998)

Berdasarkan teori dan hasil penelitian, maka dapat diperkirakan mekanisme reaksi yang terjadi seperti yang disajikan pada Gambar 5. Berdasarkan mekanisme reaksi yang diilustrasikan pada Gambar 5 yaitu, tiofen yang mendapat $\mathrm{H}^{+}$akan memutus ikatan rangkapnya, dimana salah satu karbonnya akan menjadi karbokation yang kurang stabil dan terjadi hidrogen transfer yang bersumber dari logam Co dan USY sehingga terjadi 
reaksi hingga menghasilkan produk tetrahidrotiofen. Adapun peran USY, logam Co, dan Mo dalam reaksi ini diilustrasikan dalam Gambar 5.

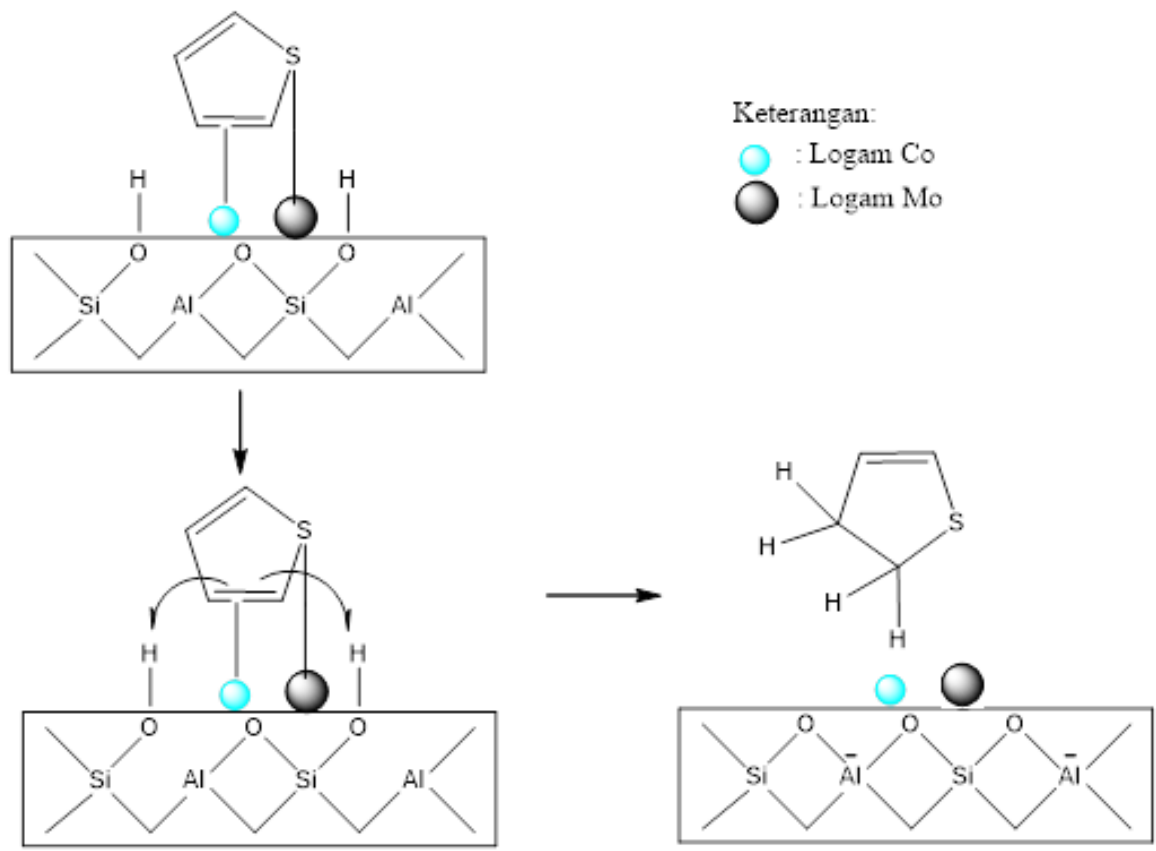

Gambar 6. Mekanisme peran USY, logam Co dan logam Mo

Berdasarkan Gambar 6, terlihat bahwa katalis dan pengemban memiliki peran yang spesifik yaitulogam Co dan USY berperan dalam hidrogenasi dan dehidrogenasi. Adapun logam Mo berperan dalam desulfurisasi, dimana logam Mo berfungsi dalam melemahkan ikatan C-S pada tiofen. Logam Co yang berperan dalam melemahkan ikatan rangkap pada tiofen, sehingga ikatan rangkap terputus dan menyerang H pada USY hingga terjadi reaksi hidrogenasi.

Karakterisasi katalis dilakukan pada salah satu katalis, yaitu pada katalis koimpregnasi CoMo/USY ditunjukkan pada Gambar 7. Berdasarkan Gambar 7 terlihat bahwa serapan gelombang pada $3400 \mathrm{~cm}^{-1}$ adanya gugus $\mathrm{OH}$ stretch, serapan gelombang pada $1700 \mathrm{~cm}^{-1}$ adanya gugus $\mathrm{OH}$ bend, pada $1060 \mathrm{~cm}^{-1}$ adanya gugus $\mathrm{Si}-\mathrm{O}-\mathrm{Si}(\mathrm{Al})$ stretch, $\mathrm{Si}(\mathrm{Al})-\mathrm{O}$ eksternal dan $\mathrm{Si}(\mathrm{Al})-\mathrm{O}$ internal $820 \mathrm{~cm}^{-1}$ dan $450 \mathrm{~cm}^{-1}$. Terlihat bahwa terjadi penurunan intensitas pada katalis bekas dibandingkan dengan katalis fresh pada gugus $\mathrm{OH}$ stretch dan $\mathrm{OH}$ bend. Fakta ini dimungkinkan karena $\mathrm{H}$ pada gugus $\mathrm{OH}$ dari USY telah berikatan dengan atom sulfur pada senyawa umpan tiofen (Popov et al., 2010). Berdasarkan analisis terhadap Gambar 7, diperoleh bahwa tidak ada perubahan serapan katalis fresh dan bekas. Tidak adanya penambahan serapan baru menunjukkan bahwa tidak ada sisa reaktan maupun pengotor yang terikat pada katalis. Namun begitu, berkurangnya 
serapan pada bilangan gelombang sekitar $3500 \mathrm{~cm}^{-1}$ dan $1600-1700 \mathrm{~cm}^{-1}$ mengindikasikan bahwa tejadi pengurangan gugus $\mathrm{OH}$ dari situs asam Bronstead katalis. Berkurangnya gugus asam Bronstead tersebut diperkirakan karena telah terjadi transfer proton dari katalis ke reaktan membentuk produk hidrogenasi yaitu tetrahidrotiofen. Hal tersebut memperkuat hasil penelitian yang menunjukkan adanya reaksi hidrogenasi.

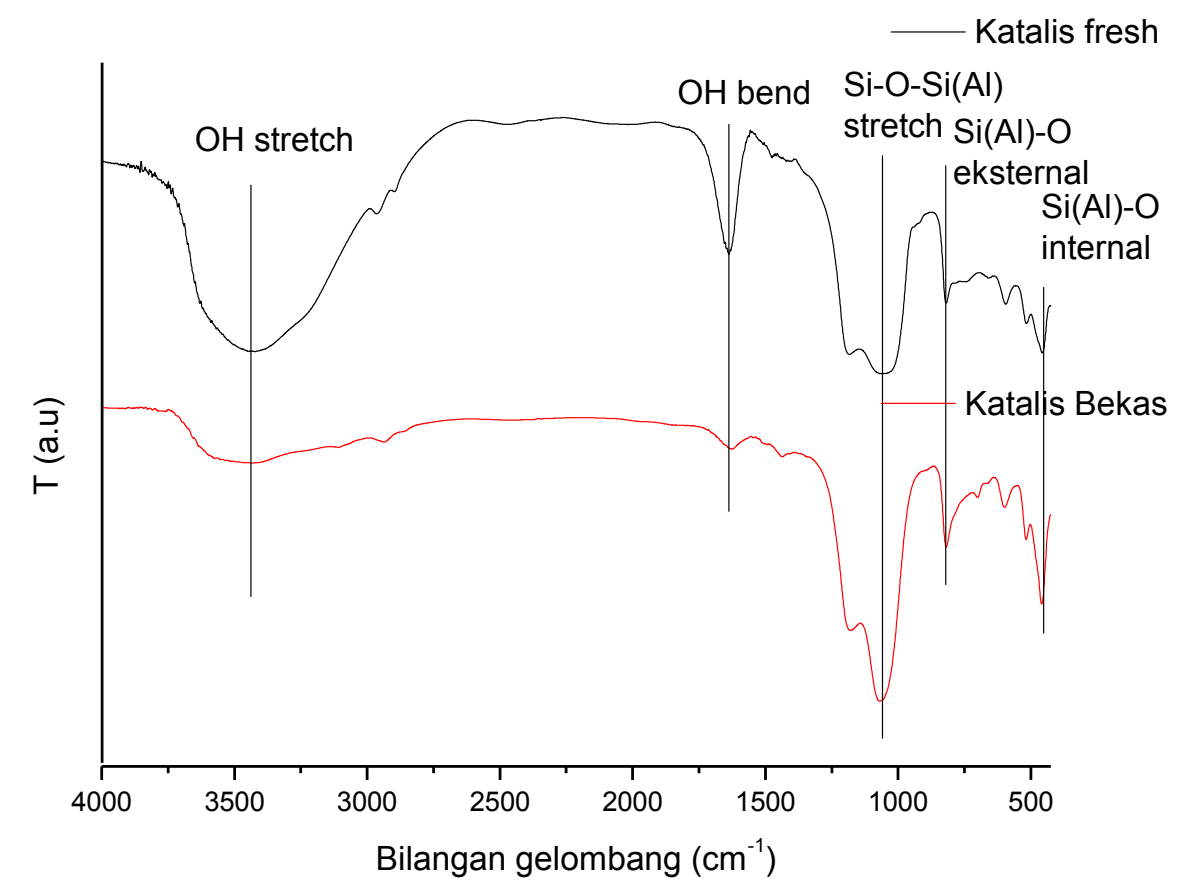

Gambar 7. Spektra FT-IR katalis fresh dan katalis bekas

\section{KESIMPULAN}

Berdasarkan hasil penelitian dan pembahasan dapat disimpulkan bahwa penelitian telah berhasil menghidrogenasi tiofen, tetapi belum bisa menghilangkan kandungan sulfurnya. Aktivitas katalis terkatalisis CoMo/USY pada rentang temperatur $200-300{ }^{\circ} \mathrm{C}$ memiliki pola bahwa semakin tinggi temperatur, maka aktivitas katalitiknya semakin tinggi pula. Aktivitas katalitik katalis berbanding lurus dengan sifat keasamannya. Katalis dengan sifat keasaman tertinggi yaitu katalis CoMo/USY memiliki aktivitas terbaik dengan rendemen sebesar $2,88 \%$.

\section{DAFTAR PUSTAKA}


Boukoberine, Y. and Hamada, B., 2016. Thiophene Hydrodesulfurization Over CoMo/Al2O3-CuY Catalysts: Temperature Effect Study. Arabian Journal of Chemistry 9, S522-S527.

Deng, L., Shinshido, T., Teramura, K. and Tanaka, T., 2014, Effect of Reduction Method on the Activity of $\mathrm{Pt}-\mathrm{Sn} / \mathrm{SiO} 2$ for Dehydrogenation of Propane, Catalysis Today, 232, 33-39.

Jarullah, A.T., Mujtaba, I.M. and Wood, A.S., 2011. Kinetic Parameter Estimation And Simulation Of Trickle-Bed Reactor For Hydrodesulfurization Of Crude Oil. Chemical Engineering Science 66(5), 859-871.

Jeevanandam, P., Klabunde, K.J. and Tetzler, S.H., 2005. Adsorption of Thiophenes Out Of Hydrocarbons Using Metal Impregnated Nanocrystalline Aluminum Oxide. Microporous and Mesoporous Materials 79(1-3), 101-110.

Larabi, C., Al Maksoud, W., Szeto, K.C., Garron, A., Arquilliere, P.P., Walter, J.J. and Santini, C.C., 2016. Design of Plurimetallic Catalysts for Solid Biomass Conversion: Batch Versus Continuous Reactors. Fuel Processing Technology 142, 192-200.

Liu, B., Zhao, Z., Wang, D., Liu, J., Chen, Y., Li, T., Duan, A. and Jiang, G., 2015. A Theoretical Study On The Mechanism For Thiophene Hydrodesulfurization Over Zeolite L-Supported Sulfided CoMo Catalysts: Insight Into The Hydrodesulfurization Over Zeolite-Based Catalysts. Computational and Theoretical Chemistry 1052, 47-57.

Moses, P.G., Hinnemann, B., Topsøe, H. and Nørskov, J.K., 2007. The Hydrogenation and Direct Desulfurization Reaction Pathway In Thiophene Hydrodesulfurization Over Mos2 Catalysts At Realistic Conditions: A Density Functional Study. Journal of Catalysis 248(2), 188-203.

Nava, R., Ortega, R.A., Alonso, G., Ornelas, C., Pawelec, B. and Fierro, J.L.G., 2007. CoMo/Ti-SBA-15 Catalysts For Dibenzothiophene Desulfurization. Catalysis Today $127(1-4), 70-84$.

Nugrahaningtyas, K.., Trisunaryanti, W., Widjnarko, D.M. and Yusnani, A., 2009. Preparation and Characterization The Non-Sulfided Metal catalyst: Ni/USY and NiMo/USY. Indonesian Journal Chemistry 9(2), 177-183.

Nugrahaningtyas, K.D., Hidayat, Y. and Saputri, T.D., 2014. Effect Of Concentration Metal Precursor Co and Mo on Character of CoMo / USY Catalyst. Alchemy: Jurnal Penelitian Kimia 10(1), 40-48.

Pawelec, B., Castaño, P. and Zepeda, T.A., 2008. Morphological Investigation of Nanostructured CoMo Catalysts. Applied Surface Science 254(13), 4092-4102.

Pawelec, B., Fierro, J.L.G., Montesinos, A. and Zepeda, T.A., 2008. Influence Of The Acidity Of Nanostructured CoMo/P/Ti-HMS Catalysts on the HDS of 4,6DMDBT Reaction Pathways. Applied Catalysis B: Environmental 80(1-2), 114.

Popov, A., Kondratieva, E., Goupil, J.M., Mariey, L., Bazin, P., Gilson, J.P., Travert, A. and Maugé, F., 2010. Bio-Oils Hydrodeoxygenation: Adsorption Of Phenolic Molecules On Oxidic Catalyst Supports. Journal of Physical Chemistry C 
114(37), 15661-15670.

Rachmadhani, 2016. Pengaruh Proses Kalsinasi dan Reduksi Terhadap Karakter Katalis Sistem Logam-Pengemban (Co dan Mo)/Ultra Stable Y Zeolite. Skripsi ed. Universitas Sebelas Maret.

Ravanchi, M.T. and Sahebdelfar, S., 2016. Pd-Ag/ $\mathrm{Al}_{2} \mathrm{O}_{3}$ Catalyst: Stages Of Deactivation In Tail-End Acetylene Selective Hydrogenation. Applied Catalysis A: General 525, 197-203.

Rawat, K., Kumar, M., Gupta, J., Bal, R., Dhar, G. and Data, A., 2010. Catalytic Functionality of NiMo and CoMo Catalysts, Supported on US-Y Zeolite for Hydrotreating Processes. In: 20th National Symposium on Catalysis for Energy Conservation of Environ pp.19-22.

Souza, M.J.B., Garrido Pedrosa, A.M., Cecilia, J.A., Gil-Mora, A.M. and RodríguezCastellón, E., 2015. Hydrodesulfurization of dibenzothiophene over PtMo / MCM-48 catalysts. Catalysis Communications 69, 217-222.

Sullivan, D.L. and Ekerdt, J.G., 1998. Mechanisms of thiophene hydrodesulfurization on model molybdenum catalysts. Journal of Catalysis 178, 226-233.

Topsøe, H., Clausen, B.S. and Massoth, F.E., 1996. Hydrotreating Catalysis. In: Catalysis $1-269$.

Torres-Mancera, P., Ramı`rez, J., Cuevas, R., Gutie'rrez-Alejandre, A., Murrieta, F. and Luna, R., 2005. Hydrodesulfurization of 4,6-DMDBT on NiMo and CoMo catalysts supported on B2O3-A12O3. Catalysis Today 107-108, 551-558.

Wang, H. and Iglesia, E., 2010. Thiophene Hydrodesulfurization Catalysis On Supported $\mathrm{Ru}$ Clusters: Mechanism and Site Requirements For Hydrogenation And Desulfurization Pathways. Journal of Catalysis 273(2), 245-256.

Wang, T., Zhang, Y., Ge, H., Tang, M., Zhou, L., Lü, Z. and Li, X., 2015. Hydrodesulfurization of Thiophene Over Mo/AC Catalyst Presulfided By Ammonium Thiosulfate. Journal of Fuel Chemistry and Technology 43(2), 202-207.

Xu, Y.-R., Shen, B.-X., Xu, X.-L., Zhang, X.-F. and Zhao, J.-G., 2011. A Study on Selective Catalytic Oxidation Desulfurization of Thiophene in Imitation Gasoline with Ti-MCM-41/H2O2-HCOOH. Energy Sources, Part A: Recovery, Utilization, and Environmental Effects 34(3), 253-260.

Yaseen, M., Shakirullah, M., Ahmad, I., Rahman, A.U., Rahman, F.U., Usman, M. and Razzaq, R., 2012. Simultaneous Operation Of Dibenzothiophene Hydrodesulfurization and Methanol Reforming Reactions Over Pd Promoted Alumina Based Catalysts. Journal of Fuel Chemistry and Technology 40(406), 714-720.

Yu, S.Y., Li, W. and Iglesia, E., 1999. Desulfurization of Thiophene via Hydrogen Transfer from Alkanes on Cation-Modified H-ZSM5. Journal of Catalysis 187, 257-261. 